\title{
WHAT ABOUT US?
}

\section{On Archaeological Objects (or the Objects of Archaeology)}

Irene Garcia-Rovira

The University of Manchester

Department of Archaeology

Mansfield Cooper, Oxford Road, Manchester M13 9PL, UK

irene.garciarovira@manchester.ac.uk

\begin{abstract}
The introduction of Object-Oriented philosophies has resulted in the development of two main attitudes to the study of the past. Some scholars have suggested the development of archaeologies that focus on the fragmentary nature of the archaeological record - inviting a more descriptive approach to doing archaeology - whereas others have used similar frameworks to revitalize the study of social processes. Both tendencies lean towards archaeologies that embrace ontological enquiry, moving away from questions of human access. In a reflection regarding things, archives and social processes, this article strives for enquiries which favour theoretical examination that encompasses the study of reality as well as the study of the ways in which archaeologists gain knowledge about the past.
\end{abstract}

Keywords: Ontology, epistemology, post-Kantian philosophies, thing, process, past, archaeological object, archaeological archive, inference, hyperobject 


\section{INTRODUCTION}

In his publication Practice and History in Archaeology: an Emerging Paradigm, Pauketat (200Ia) stressed that processes should not be understood as the outcome of practices; rather, practices should be considered the processes (Pauketat 200Ia:74). In doing so, he gave definition to historical processualism. His approach was significant as it decentred archaeologies of practice from the overly used ethnographic present (Robb 2007:292, 2013b:78), emphasizing how practice can lead to changes that are only fully grasped in wider scales of analysis. Historical processualism enabled linking what appeared to be conflicting approaches to the past by moving from the bottom up. However, this approach was soon halted by the rise of new outlooks that began to cast aside the word historical due to its connotations with narratives, defined almost exclusively through human agency. But while the word historical fell into disuse due to critiques of anthropocentrism, the very idea of process was not abandoned. In recent years, a focus on the study of processes has been reinvigorated in the hands of academics influenced by Object-Oriented philosophies and new social ontologies (e.g. Normark 2008, 20IO; Hodder 20II, 20I2; Garcia-Rovira 20I3a, in press a; Robb 20I3a, 20I4; Harris 20I4a, 20I4b).

Undoubtedly, archaeology has never completely disassociated itself from the study of processes for, in the archaeological record, they appear as the material manifestations of social dynamics in space and time. However, it is worth observing how archaeologists have traditionally chosen the notion of process to characterize profound changes observed in space and time, in contrast to social dynamics in which change can be sought in a specific socio-temporal unit (see Burström \& Fahlander 2OI 2:I-IO). Thus, whilst post-processual archaeologies typically chose to define change through the exploration of practice in specific socio-cultural milieus (e.g. Richards 2004) post-humanist and new materialist archaeologies have turned their attention to contexts of structural change for what is at stake is the examination of the ways in which the relationships established between human and non-human entities give rise to situations of emergence/becoming (Deleuze \& Guattari 2004; De Landa 2005).

This situation clearly diverges from the kind of archaeologies advocated by the supporters of symmetrical archaeology (e.g. Olsen 2003, 2007, 2012; Shanks 2007; Webmoor 2007; Witmore 2007; Webmoor \& Witmore 2008; Olsen et al. 20I2). Whilst drawing from similar sources of inspiration to argue for new understandings of society (e.g. Callon $\&$ Law 1997; Latour 1993, 1999; Law \& Hassard 1999) or for the agentic properties of things (e.g. Brown 2003; Henare et al. 2007; Bryant et al. 
20I0; Bennett 20I0), this theoretical avenue is distinguished from the former as, in the quest to take things seriously, it has promoted the necessity to embrace the fragmentary and messy nature in which archaeological objects are encountered by archaeologists. This has led some to suggest the development of a kind of archaeology that moves away from historical narratives in favour of one which is more descriptive and enhances the archaeological experience (see Olsen 20I2:25-26).

Both the revitalization of studies on social processes and the defence of archaeologies focused on things has resulted from a turn into ontological matters similar to that experienced in other disciplinary fields (see Bryant et al. 20I0:I-I9 for the discussion in philosophy). This turn has been generative and productive in that it has found new formulas into the study of social matters and has triggered a process of reflection on the nature of our discipline. Yet, in doing so, it is triggering an increasing aversion to explorations of the role that archaeologists have in the constitution of knowledge.

In this article, I want to focus on an imbalance that has been made patent by a number of scholars (e.g. Lucas 20I2; Hillerdal 20I5; GarciaRovira in press b) and that considers the weight recently granted to ontological over epistemological matters in archaeology. This article explores this theme by addressing the following questions: can the new archaeological project succeed by giving primacy to ontological matters? Is it possible to explore the ways in which knowledge is constructed in archaeology by displacing the role of archaeologists? This discussion is promoted by a context of reflection on archaeological objects, or if you wish, the objects of archaeology.

\section{RE-THINKING THINGS, RE-THINKING PROCESSES}

In 20I2, Olsen was asked to publish a reflection on the state of affairs of theoretical archaeology. At the time, he had already acknowledged his discomfort about the dynamics that the discipline had taken with the rise of post-processualism (e.g. Olsen 2003, 2010), and was about to publish another book on this matter, this time jointly with other advocates of symmetrical archaeology (see Olsen et al. 20I2). Despite that, in the article he spelled out more than ever before his dissatisfaction with archaeologies that had subjected objects to the mercy of interpretive scenarios devoted to the exploration of human endeavours. The misuse of notions of meaning and symbolism had resulted in contexts in which, as phrased by him, the depiction of an "elk, or a reindeer represent almost everything" but the thing itself (Olsen 20I2:22). Though perhaps 
caricaturing post-processual archaeologies to an unwarranted extent, Olsen $(2003,2007,2010,2012)$ and those influenced by the ontological turn occurring in the wider context of the social sciences (e.g. Normark 2006; Hicks 2007; Shanks 2007; Webmoor 2007; Witmore 2007) posed a necessary critique of anthropocentrism, bringing back the need to think about things more seriously. Their reactionary attitudes may have not represented an absolute break with previous archaeologies, as similar concerns had begun to emerge within post-processual circles (see Garcia-Rovira 20I3a; Hillerdal 20I5; Thomas 2015 for discussion). However, many would agree that this move was revolutionary.

The return to things emerging in the social sciences (see Domańska 2006a, 2006b, 2010 for discussion) proved rather interesting for archaeologists, particularly with regard to three distinct matters: society and social dynamics, the subject/object relationship and the nature of the discipline. This movement was promoted by the democratization of things. While a reaction against the forgetfulness of things had existed in the hands of scholars concerned with the textual analogy given to the archaeological record (e.g. Barrett 200I), theoretical interest in non-human agency was strictly correlated to human practice. Similarly to Gell's (I998) characterization, the agency of objects was situated in a secondary position given the lack of intentionality characteristic of human beings (Normark 2006; Harris 20I4b). The return to things promoted by the reading of post-humanist and new materialist approaches was radically different in its rejection of a duality between nature and society. Following Pálsson's characterization (I996), our relationship with things shifted from being paternalistic to a situation of communalism in which things could no longer be disjointed from social theory (Pálsson I996; Domańska 2006a:I76).

The instrumentalization of this idea led to two central lines of discussion within and outside archaeological circles (see Fowler \& Harris 2015 for discussion). On the one hand, this line of thought allowed the deployment of a new understanding of society which integrated all sorts of human and non-human entities always engaged in their relationships as a collective (Latour I993, 2005). This new theoretical regime helped to break with the anthropocentric view inherent in prevalent notions of culture and habitus and prompted the necessity to examine social dynamics incorporating agencies other than human practice. A new interest in the study of social dynamics thus developed with the implementation of flat ontologies, this time giving rise to multiscalar studies particularly interested in processes of change located in larger scales of analysis. Whereas Actor-Network Theory (ANT) had triggered the democratization of things and therefore new understand- 
ings of society, this body of theory presented the latter as an ever fluid mechanism which contrasted with the observation of periods of stability within certain social contexts. This situation was aided with the implementation of the philosophies of Deleuze and Guattari (2004) and De Landa (2005). Both the stability of its identity and the motion of an assemblage could be explained through processes of territorialization and deterritorialization (De Landa 2005; Alonso González 2012; Harris $2014 \mathrm{~b}$ ). Equally important, assemblages were not defined as a sum of their parts (see De Landa 2005:IO) but as something which cannot be irreducible, giving rise to a situation of emergence (Deleuze \& Guattari 2004; De Landa 2005).

As noted, whilst ANT theory prompted the renewal of our understandings of society in our discipline, the realist ontologies of Deleuze and De Landa, with their emphasis on notions of emergence and becoming, were highly seductive for those interested in the study of social processes. The influence exerted by these bodies of theory is particularly observable with the study of the transition of the Neolithic. Whilst the first decade of the 2000 s saw the collapse of the traditional diffusion/migration thesis in the hands of scholars influenced by practice theory (e.g. Whittle \& Cummings $2007 \mathrm{~b}$; Cummings \& Harris 20I I), the topic was profoundly reformulated. There was an acknowledgement that this process of change had to be studied taking into consideration how new relationships among human and non-human entities, derived from the introduction of new practices, gave rise to a situation of emergence, or if preferred, to new forms of sociality (Garcia-Rovira 20I3a; Robb 20I3 b; Barrett 20I4; Harris 20I4b). A renewed ontological understanding of the world allowed expressing complexity not only merging notions of nature and culture but also triggering a multi-scalar understanding of this process of change.

The influence that post-humanist and neo-materialist readings have had for the revitalization of social dynamics - and especially with those focused on notions of deep time - really contrasts with the agenda set by the founders and defenders of an archaeology understood as "a discipline of things par excellence" (Olsen 20I2:I6). These two approaches share claims about the need to think about things seriously and therefore, in the majority of cases, they emerged from similar sources of inspiration. However, it is important to note the discrepancies that exist between these lines of thought. The former continues envisaging archaeology as a discipline concerned with the construction of historical narratives - understanding historical not as a narrative centred on human endeavours but as one in which "humans define the limits of the discipline" (Lucas 20I 2:268) - whilst the latter goes as far as wishing for a "farewell to interpretation" (Olsen 20I2). In consequence, the former 
approach finds its interest in notions of time and scale (e.g. Fowles in Alberti et al. 20II; Fahlander 20I2; Robb 20I3 b) and defines archaeology as a discipline which differs from others through its accessibility to matters concerning deep time (e.g. Fowles in Alberti et al. 20I I; Robb 20I3 $\mathrm{a}, 2013 \mathrm{~b}$ ), while the latter maintains that our discipline is first and foremost a discipline of things (Olsen et al. 20I2).

The latter characterization has triggered a series of profound challenges to the discipline itself. It is argued that, with a return to things, archaeology has ceased to be a mere theory consumer to become one of the key contributors in the current intellectual landscape (Olsen 20 I 2:20; Olsen et al. 2012). Whether this can be said to be an accurate representation of the status that archaeology has gained through the current ontological turn is a matter of debate. Yet, it should not be forgotten that this line of discussion has given rise to the development of another way of thinking about archaeology which defies traditional regimes of interpretation. Instead of following modernist conceptions whereby the past is distanced from the present and the fragmentary nature of the archaeological record is filled up by historical narratives, this line of thought urges us to embrace the messiness and fragmentary nature in which the past is manifested, prompting a more descriptive archaeology which enhances the incompleteness of things and the archaeological experience (see Olsen 2OI 2:25-26). As Olsen nicely puts it, the challenge is to cease seeing "the past as history and the present as non-archaeology” (Olsen 20I2:I2).

\section{SOCIAL THEORY, POLITICS, SELF-REFLECTION ... WHAT ABOUT EPISTEMOLOGY?}

[...] 'theory' has, historically, tended to confine itself to a delimited set of topics. Where 'new archaeology' did openly articulate theory, it did so with reference to two areas: epistemology and questions of social reconstruction and process [...]. Marxist, postprocessual and related strands of archaeology added a third area, or arguably drew out into the open a third area that was always more or less latent and implicit: the reflexive and political nature of archaeology [...] (Johnson 2006:119) (my emphasis).

In 2006, Johnson published a compelling reflection on the nature of archaeological theory. In it, he noted that this branch of archaeology has been constituted by three main realms of thought: social theory, epistemology and the reflexive and political matters affecting the discipline (see the quotation above). New ways of looking at society and at social dynamics had resulted from the incorporation of, for instance, systems 
theory (e.g. Binford 1965; Flannery 1968) or practice theory (e.g. Barrett I988, 200I). Epistemological questions had already been raised in the late I930s and I940s with those openly discussing the usefulness of archaeological categorization (e.g. Colton I932; Taylor 1948). Discussions on the objective nature of our inferences had been key within processualism (e.g. Binford 1989) and an opposite reaction appeared soon after with the development of hermeneutics (e.g. Shanks \& Tilley 2007 in relation to archaeological classification). Finally, reflexive and political matters had been openly drawn with writings such as The Craft of Archaeology (Shanks \& McGuire 1996). Sufficient years have now passed since the first post-humanist and neo-materialist writings appeared in our discipline; time enough to ask the following question: in what ways have these archaeologies touched upon the realms of thought defined by Johnson (2006)?

In the last section, I discussed how the application of new social ontologies triggered a renewed interest in past processes (e.g. Burström \& Fahlander 20I2; Robb \& Pauketat 20I3; Harris 20I4a, 20I4b). Similar to the ways in which Heidegger's ontology (1962) - and consequently Bourdieu's (1977) and Giddens's (1984) theories of practice - had been deployed in archaeology as a way of thinking about social dynamics (e.g. Thomas 1996), the new social ontologies of Deleuze (2004) and De Landa (2005) -among others - have triggered renewed interest in the definition of society, agency and subsequently the examination of social processes. New theoretical avenues derived from a turn to things have therefore had an impact on matters of social theory in archaeology.

Similarly, the democratization of things has prompted a reflection on the discipline itself (e.g. Olsen 20Io; Olsen et al. 20I2) and has had clear political undertones, as demonstrated by the writings of the founders of symmetrical archaeology (e.g. Webmoor \& Witmore 2008). Their earliest writings are nothing but a statement of intentions about the future of archaeological practice. But while new theoretical waves have touched upon social theory and political matters, have they triggered a renewed concern over questions regarding the construction of knowledge? Great care has to be taken in order to answer this question to avoid unwanted misunderstandings.

Post-humanist and new materialist archaeologies, in their quest to overcome human exceptionalism, have often referred to ontology as a way of breaking with what are considered to be epistemological limitations mirroring a situation clearly seen in other branches of the social sciences. In the same way that, for instance, Latour (1993) had indicated that the modern birth of the human triggered a deep separation between humans and non-humans (Olsen et al. 2012:19), archaeologists 
have used a similar proposition to break through the restrictions placed by prevailing binaries such as nature and culture (Harris 20I4b). At an increasing depth, archaeologists, following the steps of contemporary philosophers and social theorists (e.g. Domańska 2006a, 2006b; Bryant et al. 2010), have been able to point at the flaws of linguistic paradigms which had notoriously correlated thinking with being (see Meillasoux 2008). With regard to archaeological objects, archaeologists have followed similar steps by denouncing how linguistic approaches have always envisaged a thing as something (Heidegger I962; Brandom 2005), obliterating the very agentic properties of the thing itself.

Yet, while, as already mentioned, in their writings they often refer to ontology as a way of breaking with epistemological limitations (see e.g. Harris 20I4a), this statement may be more accurately read as ontology being used to break with the central position given to human beings in the constitution of knowledge, rather than a clear rejection of epistemological enquiry. In actual fact, epistemological discussion has not been abandoned but reenergized, particularly by symmetrical archaeologists. Clearly influenced by Actor-Network theory (e.g. Callon \& Law I997; Latour I993, I999; Law \& Hassard I999), they have stressed the amalgam of human and non-human actants that are at play in the constitution of past knowledge. This notion is elegantly explored by Edgeworth (20I2) in an account that demonstrates how knowledge is generated in the process of digging, using as example the act of following a cut. $\mathrm{He}$ stresses that our interpretations cannot be explained as a response of an observer directing attention to the observed. In contrast, interpretation is always subjected to the interplay that occurs between us, the soil, the tools, the actual cut and so forth in the process of digging. It is amidst this set of relationships that knowledge is produced. An acknowledgement of the networks that help constitute knowledge about the past has led, over time, to an opening of the discussion to include more specific questions of epistemology such as representation and the use of media in archaeology (e.g. Webmoor 2005, 20I4; Witmore 2006; Shanks \& Webmoor 20I2).

Thus, the growing popularity of flat ontologies has led to new ways of thinking about epistemological conundrums in which human beings are displaced from the centre. In archaeology, this turn has been incredibly generative not only because it has overruled the idea of archaeologists as agents interpreting inert matter but also because it has opened up theoretical contemplation of contexts (e.g. post-excavation process) which have been traditionally undertheorized (see next section for discussion). However, all theoretical advances come with a space for critique, and in this text I would like to question whether using flat ontologies as a way of challenging post-Kantian thought necessarily precludes 
any theoretical contemplation of the role that human beings (and by extension, archaeologists) have not only in the constitution of understandings of the past but also of the very idea of past itself. Should speculating about reality necessarily conflict with thinking about the ways in which we create knowledge?

\section{ARCHAEOLOGICAL OBJECTS (OR THE OBJECTS OF ARCHAEOLOGY)}

The kind of correlation defined by Meillasoux (2008) in relation to postKantian philosophy denotes a direct link between thinking and being. With that, it follows that correlational philosophies have either taken to believing that reality does not exist outside the contents of the human mind or that it does, although doubting phenomena that are not observable by human perception (Alonso González 20I 2:I5-I6). What is significant about Meillasoux's observation is that it demonstrates that since Kant, ontological approaches have continuously been founded upon questions of human access; a reflection stimulated by considering the ontological status of things (see Bryant et al. 20Io). Following this line of thought, it appears possible to indicate that the question of what an object is should be clearly isolated and set apart from the question of how we know objects (Bryant 20I1a:I8). This turn has been particularly challenging within and outside philosophical enquiry. In archaeological discourse, objects are no longer considered as matter used by humans to achieve their ends; human agency no longer transcends that of other beings and, as result, social processes can no longer be defined through human practice alone.

Yet, in their turn to ontology, Object-Oriented Philosophies have not necessarily overruled the significance that questions of human access have in philosophical enquiry. Rather it is remarked that questions on the nature of reality should not be answered by noting how humans experience it. Ontology is thus displaced from any notions of human transcendence while ontology and epistemology are still regarded as distinct branches of philosophical enquiry. This position is expressed by Bryant (20IIa) who states that:

[...] flat ontology readily recognizes that humans have unique powers and capacities and that how humans relate to the world is a topic more than worthy of investigation, yet nothing about this establishes that humans must be included in every inter-object relation or that how humans relate to objects differs in kind from how other entities relate to objects (Bryant 20I Ia:246). 
In this quotation, Bryant (20IIa) dissolves the aforementioned opposition by noting that it is as significant to speculate about reality as it is to direct observation to how reality is experienced by objects with specific capacities - human beings - as long as these meditations are set apart from one another. This reflection is particularly significant for us archaeologists as it enables us, at one and the same time, to recognize the past as a reality and as a very specific concept that can only be grasped by reintroducing the role of human beings into the equation.

In this section, I wish to argue that the growing opposition between the nature of reality and how we perceive can be dismantled, at least in archaeology, by looking more closely at our practices. This move, as I hope to demonstrate, does not signify the return to a correlational theories. It simply wants to draw attention to the nature of the discipline; the very constitution of archaeological knowledge demands a recognition of the past as a reality outside the contents of the human mind, but its form is dependent upon the way it is conceptualized by human beings through processes of inference. This discussion is promoted by a particular question: what is an archaeological object, or so to speak, the object of archaeology?

\section{THINGS AND ARCHAEOLOGICAL OBJECTS}

Those seeking for a discipline devoted to the study of things (e.g. Olsen et al. 2012) have denounced how archaeologists have neglected them in their quest to construct historical narratives, for the latter involves seeking what is precisely absent in material remains: their association with past contexts and to people. Pondering about this reflection, one may wonder what we are doing when conceptualizing pottery fragments such as the ones shown in the image below (figure I) - as fragments of Grooved Ware that tie into narratives about Orcadian identity and that are central in the explanation of social change during the third millennium BC. Why does archaeological interpretation hardly ever consider archaeological objects as the fragmentary remains of things that were assembled in the past and that continue to exist in the present? The paradox posed by this line of thought presents real challenges to the discipline. Yet, a problem emerges in defining archaeology as a discipline of things for what is absent in things is precisely what offers the qualities of archaeological objects.

Lucas (20I2) emphasizes this view by reminding the reader how "the presence of humans is what defines the archaeological and separates it from [...] the geological or paleontological record [...]" (Lucas 

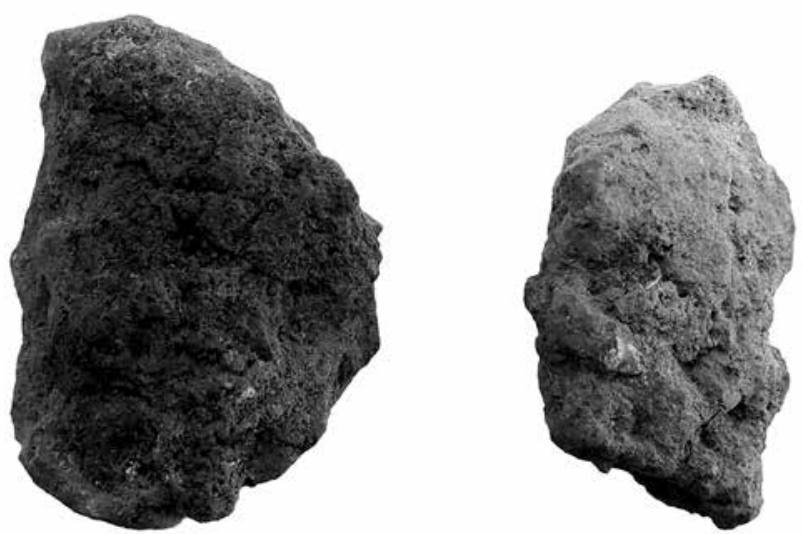

Figure I. Fragments of Grooved Ware found at Barnhouse (Orkney Islands, UK).

20I 2:260). However, he is quick to accentuate that this position does not place human beings at the centre of archaeology. Rather, "humans simply define its limits" (Lucas 20I 2:260). This position can be nicely illustrated in pointing at the very definition of negative trenches. While two distinct trenches located close by may evidence identical stratigraphic sequences (e.g. successive episodes of colluvium formation resting on top of the natural), only that containing evidence of human activity is regarded as being of archaeological interest.

The other quality to be found in archaeological objects relates to their pastness. Certainly, archaeological objects exist insofar as they are elements which occur in the present. However, if an object is not regarded as past then it is "no less contemporary than the showcase in which it rests" (Hillerdal 20I5:I46). As Holtorf notes, "archaeological objects can be defined as objects that possess pastness" (Holtorf 20I3:43I).

Fundamentally, our awareness of a past object is determined by its materiality. In our example (figure I), our pottery sherds are crumbling away every time they are picked up; the presence of mud in the grooves suggests that they were once unearthed, and the material properties that once held the pot together are quickly disintegrating. On other occasions, its pastness is discerned according to the context in which the object was found. The authenticity of an archaeological object is therefore subject to its relation to past and to people, and it is dependent upon its existence in the present (see Hillerdal 2015 for discussion). Nonetheless, as Holtorf (20I3) stresses, definitions of objects' pastness also require considering how their authenticity is established once it matches the expectations of the audience, and it is substantiated by the definition of histories relating objects between then and now (see Holtorf 2013:432-435). 


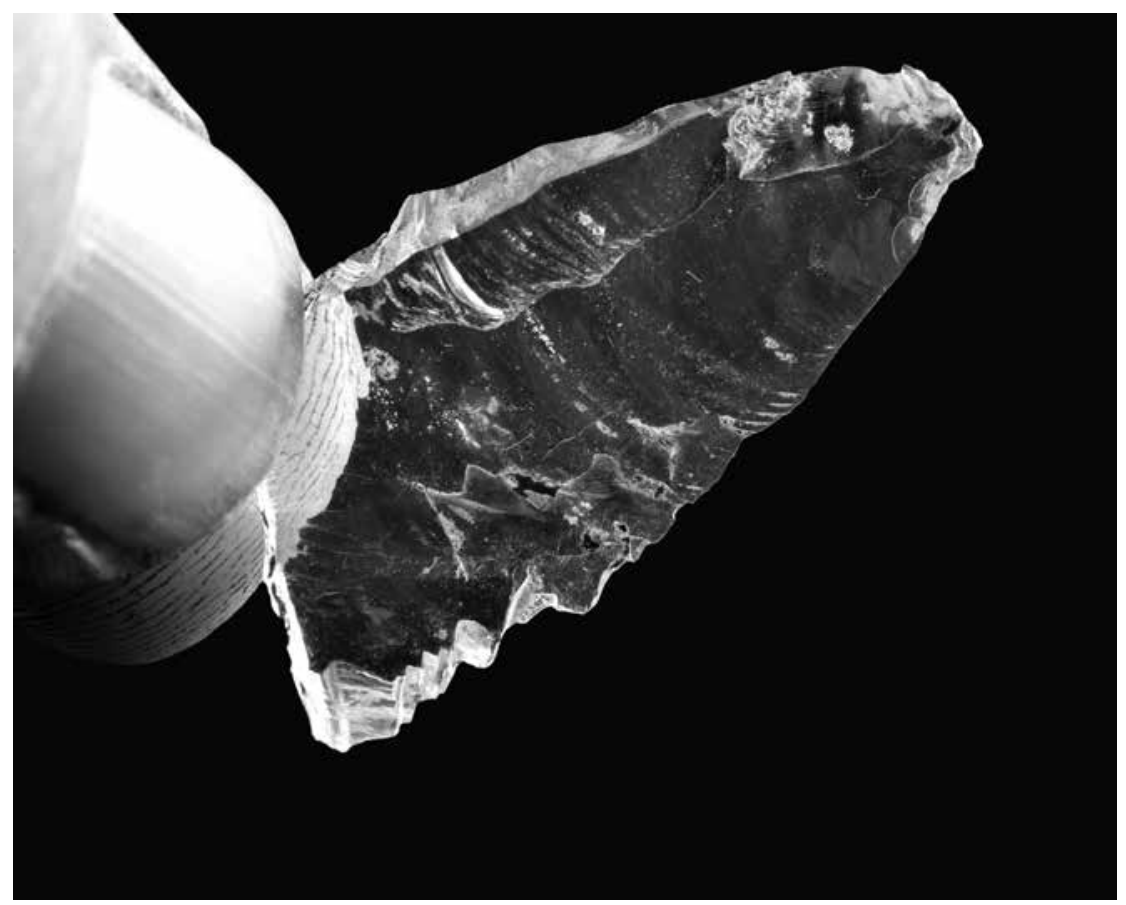

Figure 2. Rock crystal flake found in pit [136] at Dorstone Hill (Herefordshire, UK).

The position so far outlined can be briefly illustrated with the following example. In 20I3, excavations carried out at the site of Dorstone Hill (Herefordshire, UK) recovered four fragments of rock crystal. The rarity of such finds immediately became one of the most debated issues on site. The fragments were recovered from a well-sealed pit - feature [136] - in which 35 pottery sherds, nine flint flakes and a tip of a flint arrowhead were also found (see Thomas et al. 20I4, unpublished report). Interestingly, while these finds were retrieved from a secure context, the very materiality of these objects - resembling modern glass by their translucent qualities and their sharp breakage - triggered discomfort among the digging team. Were these material remains found in a wellsealed context? Or were they fragments of modern glass found in a disturbed layer at the site? Fortunately, on closer inspection it was possible to verify that these were in fact fragments of rock crystal and that, at least I fragment had been worked (figure 2). A further assemblage was subsequently found in a pit-like feature (figure 3 ) - feature [5 18$]$ - during the 20I4 excavations at the same site which supported the authenticity of such finds (see Garcia-Rovira et al. 2015, unpublished report). The fragments of rock crystal were finally regarded as archaeological objects (figure 4 ). 

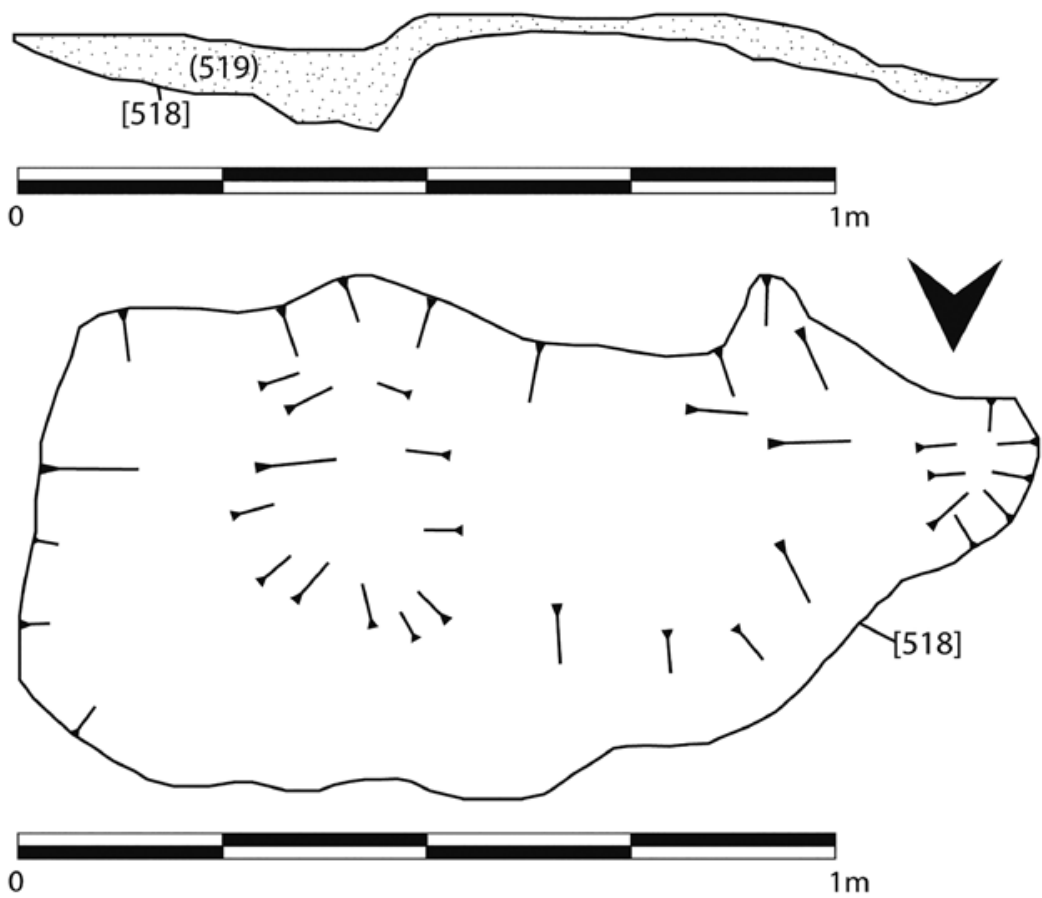

Figure 3. Plan and section of feature [518] found at Dorstone Hill (Herefordshire, UK).

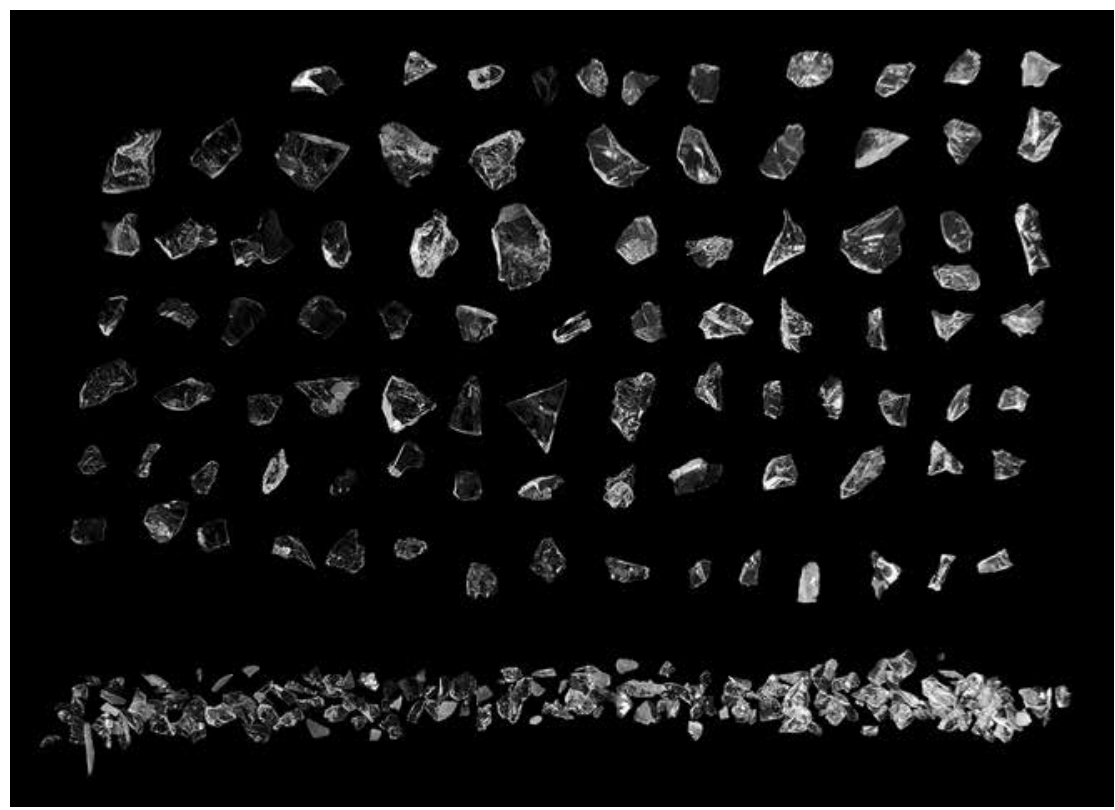

Figure 4. Rock crystal fragments recovered from fill of feature [5 I8] at Dorstone Hill (Herefordshire, UK). 
In acknowledging that the authenticity of archaeological objects is subject to their relationship to two qualities which are absent and therefore differed through human engagement with materiality, we are not necessarily contemplating the idea that the past only exists as result of human conceptualization. The past is a reality that has effects outside the contents of the human mind and it is therefore worth considering ontologically. However, in the very definition of archaeological objects, the past is approached in our discipline through processes of inference. Even those who wish to approach archaeological objects in more descriptive ways are forced to establish such inferences in their determinations of what an archaeological object is. In the light of such a situation, it may be argued that any approach to the study of archaeological objects requires contemplation of the nature of reality and of how the past is conceptualized by the archaeological eye. This view does not preclude the importance of acknowledging symmetrical archaeology's emphasis on the multiplicity of actants that participate in the production of understandings about the past. In its place, it draws attention to the necessity to direct attention to very the conditions of potential for our discipline; conditions directly derived from inferential engagement that occurs to entities with specific capacities - human beings.

\section{ARCHIVES AS ARCHAEOLOGICAL OBJECTS}

Sometimes I felt the magic took place off-stage or behind the curtain, and that interpretations were presented without specifying how information had been collected, presented or processed. (Fowler 20I3:4)

To this point, it has been argued that archaeological objects are defined by their relation to human beings and to pastness - elements which cannot be completely disjointed from human inference. Archaeological objects are the objects of archaeology but their primacy may be questioned in acknowledging that the latter should integrate all those elements from which the past emerges. While this may be the case, the epistemological primacy (Shanks \& Webmoor 20I2) given to materiality in archaeology is patent at a number of levels.

Degrees in archaeology have a tendency to emphasize material culture and synthesis, underestimating the role that post-excavation has in the production of understandings about the past (see the quotation above). In archaeological excavations, paper records are often considered representations of what was once there. At a deeper level, the primacy given to past materiality has had direct effects on the manners in which the 
archaeological record has been defined to date. In all its articulations - the fossil record, the textual record or the record of human practice (see Patrik 1985; Barrett 200I) - examinations of the archaeological record have been excessively focused on the material remains we excavate.

Fortuitously, though, the epistemological primacy traditionally given to past materiality has been questioned with the recognition that past understandings emerge out of what symmetrical archaeologists (e.g. Olsen et al. 2012:38), following Stengers (2005), have defined as an ecology of practices. Retaking Edgeworth (2OI2), the interpretation of a cut occurs through the immediate encounter of tools, soil, weather, expectations and so forth. The materialization of this understanding has led to the assertion that archaeological archives are not just representations of the archaeological record (see Lucas 20I2; Fowler 20I3) but have to be understood in terms of emergence because this is what gives rise to the past (see Lucas 2012 for discussion). If the past emerges in the very constitution of an archive, the latter may also be considered an archaeological object. This positioning necessarily takes us to two equally significant reflections.

The first element of discussion derives from the recognition that, unlike past materiality, archaeological archives have not yet been openly discussed in archaeological theory. While this situation is different from place to place, the records produced in and after an excavation are more often than not considered to be a representation of the past rather than the past itself. As such they are constituted following standardized recording methods and deposited following guidelines habitually defined to allow conservation and preservation (see Baird \& McFadyen 20I4; Garcia-Rovira \& Alegria-Tejedor in prep.). Yet, in understanding archives as archaeological objects, matters of concern are no longer limited to the ways in which archives are structured, conserved and accessible by future generations. The ethical responsibilities of archaeologists extend to incorporate the need to articulate the ways in which knowledge about the site has been gained, not only through a direct observation between materiality and archaeologists but through the very intimate set of relationships that are forged among a multiplicity of actants in the act of digging a site. Let us take the excavation of Dorstone Hill (Herefordshire, UK) to illustrate this position.

Central to the excavations at the site was a particular context (5II) established through the remains of a fired structure made of wattle and daub. In contrast to every other context, 5 II presented real challenges to the team as, due to its heterogeneity (the layer integrated burn wood, decayed wood, wattle and daub and clay among other things), it defied all the standardized recording methods used onsite. In the grand scheme 
of things, the limits imposed by the recording sheets were circumvented by writing detailed descriptions of the layer. As such, burnt planks following well-defined patterns could be defined as evidence for the skeleton of a once standing structure and the wattle and daub as the fabric of once standing walls. This descriptive account allowed the team to handle the layer accurately, with the exception of the more ambiguous elements of the layer which were more often than not experienced in the very act of excavation and through the intervention of a number of factors, including the kind of trowel you were using, the responses to the soil after periods of rain or the effects that cloud cover had on the site. If knowledge about the past is considered to emerge amidst these collective interventions; if archives are considered archaeological objects as such, should these more intimate dealings be central to the act of recording a site?

The second element of discussion takes us back to the argument pursued in this section. With regard to objects it has been suggested that the very constitution of archaeological object demands human inference and as such the latter should also be a matter for theoretical contemplation. Similarly, while the production of archives should not be disassociated from all the other factors that play a role in the constitution of archaeological knowledge, it is significant to highlight that records/archives are constituted by us and therefore they should not be completely withdrawn from human intention and the ways in which we conceptualize the past. This suggestion does not presume that the past does not exist outside human conceptualization but that the emergence of past understandings occurs through an overlap of the past as a reality and the past as conceptualized by the archaeological eye.

\section{PAST PROCESSES AS ARCHAEOLOGICAL OBJECTS}

At the beginning of this article, I argued that while the ontological turn has led to the definition of archaeologies focused on the study of things, similar sources have been used to reengage in the study of social processes. In the grand scheme of things, this turn has triggered awareness of the complex web of agents that, in assembly, trigger situations of emergence. Likewise, the introduction of new social ontologies (e.g. Latour 1999; Deleuze 2004; De Landa 2005) has given insight into the multitemporal character of processes of change, and has allowed breaking with top-down approaches that depict abstract forces imposing changes in the kind of things that happen on the ground (see Fahlander $20 \mathrm{I} 2$ for discussion). In every case, a turn to ontology has greatly enhanced 
the possibilities that archaeologists have to examine changes that occur in large temporal and spatial contexts. Yet, some may retreat from the possibility of their study, noting that processes are products of human conceptualization rather than real entities.

A number of scholars remind us that archaeological objects are things that existed in the past and, more importantly, continue to exist in the present (e.g. Hillderdal 20I5; Lucas 20I2; Olsen et al. 20I2). This statement presents a paradox in considering the agentic properties of objects for it "emphasises that past is everywhere present and active" (Webmoor 2007:575). In their life spans, archaeological objects have been entities of many assemblages, thus presenting questions of whether it is possible and, if at all, necessary, to continue searching for their original affiliation. This reflection has led symmetrical archaeologists to turn against "a typological understanding of time and its classificatory relation to history" (Olsen 20I2:6). Given that processes such as the transition to the Neolithic require operations related to notions of human access, the authenticity of such processes may be questioned. But what would occur if past processes were to be considered objects?

In The Ecological Thought, T. Morton (20I0) rightly emphasizes that, despite their success, Object-Oriented philosophies have not fully removed questions of human access in focusing their attention on the study of objects of lived experience (see Morton 20Io for discussion), thus failing to reach the demands of philosophical enquiry which sees ontology as first philosophy. The same can be said to have occurred in archaeology in defining things (of lived experience) as archaeology's object of study. Morton's observations may trigger questions about the translation of new social ontologies to archaeology. Yet, on this occasion, it appears interesting to delve into the possibilities he poses for the existence of objects that defy human experience of them. Could past social processes be said to be akin to Morton's hyperobjects? If so, what would be the implications of such a move? These questions may be discussed by using a particular example: the process of change traditionally defined as the transition to the Neolithic.

The transition to the Neolithic in Europe is known to have spanned more than three millennia ( 7 th to $5^{\text {th }}$ millennium cal. BC). Despite divergences regarding its nature and character, it has been acknowledged that this process occurred amid particular relationships that were triggered through the incorporation of new practices within particular environments. Given the mosaic of environments and idiosyncrasies in which these practices were implemented, it is necessary to emphasize that this process led to the definition of multiple contexts of transformation evidenced regionally (see Whittle \& Cummings 2007). This is particu- 
larly interesting as, at the other end of the spectrum - the macro-scale this context of change appears to result in situations of convergence; of new forms of sociality which are defined by the impossibility to revert to previous ways of living (Robb 20I3a; Garcia-Rovira 20I3a). While it may be argued that the macro-scale characterization of the transition results from processes of human conceptualization, the similarities it shares with Morton's hyperobject (20IO, 20II) are worth considering in some detail. In effect, by looking at the transition at a macro-scale, an element stands out: if the transition as a whole was to be treated as an object, then the latter should be considered greater than the sum of its relations (see Morton 20I0; Bryant 20I Ib:9I), for as has been noted, the mosaic-like situation evidenced resulted in a situation of convergence, that is, in the definition of new forms of sociality. Moreover, as is the case with Morton's hyperobject, this process of change proved viscous (see Morton 20I0) as, once immersed in the adoption and reproduction of new practices, it became impossible for social groups to revert to previous lifeways.

What is important for the argument pursued is Morton's definition of a kind of objects which are so dispersed in time and space that they transcend any spatial and temporal barrier (Morton 20I0:I30). His definition means that these objects cannot be perceived by other entities and have different temporalities (Morton 20I0:55-80). Undeniably, this may have been the situation for those who experienced changes associated with the introduction of new practices during the transition to the Neolithic. Yet, the situation diverges when we consider the ways in which these objects can be perceived by those - archaeologists - who delve into matters existing across space and time. Even from this vantage point, processes cannot be envisaged in the same way as an object of lived experience. Processes, however, like archaeological objects, can be defined in conflating reality and inference. It has already been noted that processes such as the transition to the Neolithic should not be conceptualized as changes caused by a series of abstract forces but by the dynamics triggered, in this case, amid new relationships associated with the implementation of new practices. In this case, the very materiality of such events speaks of a reality that stands outside human conceptualization. But like Morton's hyperobject, the totality of the process cannot be realized in any particular local manifestation. Thus in the same way as a hyperobject is defined, processes - understood as objects - differ through their local manifestations in processes of inference. 


\section{CONCLUSIONS}

The influence exerted by the ontological turn in archaeology has so far resulted in the development of two main strands of research: one which draws attention to the study of things, and one which focuses its efforts on the examination of phenomena distributed in large temporal and spatial scales of analysis. Despite the differences that exist between them, these approaches have turned to ontological matters, often as a way of releasing the discipline from what are considered epistemological restrictions. As has been noted in this text, by epistemological limitations, these tendencies actually indicate the need to move away from human exceptionalism to explore the ways in which the constitution of knowledge occurs through the multiplicity of agents. Translated to our discipline, the past is no longer constituted through direct observation of inner matter but through multiple elements rightly defined as an ecology of practices.

Adopting a relational approach to the study of our practices, it has been possible to expand our understandings of archaeological objects to integrate all those elements from which the past emerges. This has enabled displacing materiality from its position of epistemological primacy to include archives and concepts (see Lucas 20I3; Fowler 20I3 for further discussion). This move has been allowed by a shift towards the question of the past as a reality rather than as a product of human conceptualization. However, through a discussion of what constitutes archaeological objects, or the objects of archaeology, it has been pointed out that archaeological interpretation cannot be completely disassociated from human inference. The latter plays an equally important role in the definition of past materiality; it is imprinted in the very exercise of constructing an archive and it is latent in our conceptualization of the past. Following from this discussion, and as a way to take this text to a closure, I would like to ask the following question: rather than positioning archaeology within realist or correlationist frameworks, could it be said that archaeological interpretation emerges out of an encounter of the past as a reality and the past as conceptualized by the archaeological eye? What kind of consequences would the acceptance of this premise have for archaeological theory?

\section{ACKNOWLEDGEMENTS}

I am grateful to Julie Birchenall, Emma Tollefsen and David Jennings for reading the text. All errors are of course my own. 


\section{REFERENCES}

\section{Literature}

Alberti, B., Fowles, S., Hoolbrad, M., Marshall, Y. \& Witmore, C. 20I I. Worlds Otherwise: Archaeology, Anthropology, and Ontological Difference. Current Anthropology. Vol. 52:6. Pp. 896-9I2.

Alonso González, P. 20I 2. Flanqueando el procesualismo y posprocesualismo: Arqueología, teoría de la complejidad y la filosofía de Gilles Deleuze. Complutum. Vol. 23:2. Pp.I3-32.

Baird, J. A. \& McFadyen, L. 20I4. Towards an Archaeology of Archaeological Archives. Archaeological Review from Cambridge 29:2 (The Archive Issue). Pp. I 4-32.

Barrett, J. C. 1988. Fields of Discourse: Reconstituting a Social Archaeology. Critique of Anthropology. Vol. 7. Pp. 5-16.

Barrett, J. C. 200I. Agency, the Duality of Structure, and the Problem of the Archaeological Record. In: Hodder, I. (Ed.). Archaeological Theory Today (Ist edition). Pp. I4I-I64. Cambridge: Cambridge University Press.

Barrett, J. C. 20I 4. Some Possible Conditions Necessary for the Colonisation of Europe by Domesticates. In: Whittle, A. \& Bickle P. (Eds). Early Farmers: A View from Archaeology and Science. British Academy. Vol. I38. Pp. 39-5I.

Bennett, J. 20Io. Vibrant Matter: A Political Ecology of Things. Durham: Duke University Press.

Binford, L. R. I965. Archaeological Systematics and the Study of Cultural Process. American Antiquity. Vol. 31:2. Pp. 203-210.

Binford, L. R. 1989. Debating Archaeology. San Diego: Academic Press.

Bourdieu, P. I977. Outline of a Theory of Practice. Cambridge: Cambridge University Press.

Brandom, R. 2005. Heidegger's Categories in Being and Time. In: Dreyfus, H. L. \& Wrathall, M. A. (Eds). A Companion to Heidegger. Pp. 21 4-232. Oxford: Blackwell.

Brown, B. 2003. A Sense of Things: The Object Matter of American Literature. Chicago: Chicago University Press.

Bryant, L. 20Io. The Ontic Principle: Outline of an Object-Oriented Ontology. In: Bryant, L., Srnicek, N. \& Harman, G. (Eds). The Speculative Turn: Continental Materialism and Realism. Pp. 26I-278. Melbourne: re. press.

Bryant, L. 20I Ia. The Democracy of Objects. University of Michigan: Michigan Publishing.

Bryant, L. 20IIb. On the Reality and Construction of Hyperobjects with reference to class. Speculations II. Pp. 86-103.

Bryant, L., Srnicek, N. \& Harman, G. 20Io. The Speculative Turn: Continental Materialism and Realism. Melbourne: re. press.

Burström, N. M. \& Fahlander, F. 20I2. Matters of Scale: Processes and Courses of Events in the Past and the Present. Stockholm: Stockholm Studies in Archaeology 56.

Callon, M. \& Law, J. 1997. After the Individual in Society: Lessons on Collectivity from Science, Technology and Society. Canadian Journal of Sociology. Vol. 22:2. Pp. I65-I82.

Colton, H. S. 1932. A Survey of Prehistoric Sites in the Region of Flagstaff, Arizona. Bureau of American Ethnology Bulletin I04. Washington, DC: U.S. Government Printing Office. 
Cummings, V. \& Harris, O. 20I I. Animals, People and Places: The Continuity of Hunting and Gathering Practices across the Mesolithic-Neolithic Transition in Britain. European Journal of Archaeology. Vol. I4. Pp. 36I-393.

De Landa, M. 2005. A New Philosophy of Society: Assemblage Theory and Social Complexity. London: Continuum.

Deleuze, G. \& Guattari, F. 2004. A Thousand Plateaus: Capitalism and Schizophrenia. London: Continuum.

Domańska, E. 2006a. The Return to Things. Archaeologia Polona. Vol. 44. Pp. I7II 85 .

Domańska, E. 2006b. The Material Presence of the Past. History and Theory. Vol. 45. Pp. 337-348.

Domańska, E. 20Io. Beyond Anthropocentrism in Historical Studies. Historein. Vol. Iо. Pp. I $18-$-130.

Edgeworth, M. 20I 2. Follow the Cut, Follow the Rhythm, Follow the Material. Norwegian Archaeological Review. Vol. 45:I. Pp. 76-92.

Fahlander, F. 20I2. Articulating Hybridity: Structurating Situations and Indexical Events in North-European Rock Art. In: Burström, N. M. \& Fahlander, F. (Eds). Matters of Scale: Processes and Courses of Events in the Past and the Present. Stockholm: Stockholm Studies in Archaeology 56. Pp. 53-74.

Flannery, K. V. 1968. Archaeological Systems Theory and Early Mesoamerica. In: Meggers, B. J. (Ed.). Anthropological Archaeology in the Americas. Pp. 67-87. Washington: Anthropological Society of Washington.

Fowler, C. 2013. The Emergent Past: A Relational Realist Archaeology of Early Bronze Age Mortuary Practices. Oxford: Oxford University Press.

Fowler, C. \& Harris, O. 20I 5. Enduring relations: exploring a paradox of new materialism. Journal of Material Culture. Vol. 20:2. Pp. 127-48.

Garcia-Rovira, I. 20I3a. The Indian behind the artefact or the artefact behind the process? Humans non-humans and the transition to the Neolithic. Current Swedish Archaeology. Vol. 21. Pp. 73-9I.

Garcia-Rovira, I. in press a. Dialogues in Transition: Between Entanglements and Hybridities. In: Clack, T. (Ed.). Material Hybridity: Archaeologies of Contact. Oxford: Oxford University Press.

Garcia-Rovira, I. in press b. In Dialogue: From Social Analysis to Epistemological Concerns. In: Debert, J., Thomas, J., Larsson, M. \& Garcia-Rovira, I. (Eds). In Dialogue: Tradition and Interaction in the Mesolithic-Neolithic Transition. Oxford: British Archaeological Reports.

Garcia-Rovira, I. in preparation. Cultural Encounters, Time, and the Formation of Hybrid Identities: Exploring Social Change in the Orkneys at the Turn to the Third Millennium BC.

Garcia-Rovira, I., Alegria-Tejedor, W. in preparation. The Archaeological Archive: Ethical Questions and our Contemporary Context.

Gell, A. 1998. Art and Agency. Oxford: Oxford University Press.

Giddens, A. 1984. The Constitution of Society: Outline of Structuration. Cambridge: Polity Press.

Harris, O. J. T. 20I 4a. (Re) Assembling Communities. Journal of Archaeological Theory and Method. Vol. 2I. Pp. 76-97. 
Harris, O. J. T. 20I 4b. Revealing Our Vibrant Past: Science, Materiality and the Neolithic. In: Whittle, A., Bickle, P. (eds.) Early Farmers: A View from Archaeology and Science. London: British Academy 198. Pp. 327-345.

Heidegger, M. 1962. Being and Time. Oxford: Blackwell.

Henare, A., Holbraad, M. \& Wastell, S. 2007. Thinking Through Things: Theorising Artefacts Ethnographically. London: Routledge.

Hicks, D. 2007. From Material Culture to Material Life. Journal of Iberian Archaeology. Vol. 9:IO. Pp. 245-55.

Hillerdal, C. 2015. Empirical Tensions in the Materialities of Time. In: Hillerdal, C. \& Siapkas, J. (Eds). Debating Archaeological Empiricism: The Ambiguity of Material Evidence. Oxford: Routledge Studies in Archaeology.

Hodder, I. 20I I. Human-thing Entanglement: Towards an Integrated Archaeological Perspective. Journal of the Royal Anthropological Institute. Vol. 17. Pp. I54-I77.

Hodder, I. 20I2. Entangled: An Archaeology of the Relationships between Humans and Things. Malden: Wiley-Blackwell.

Holtorf, C. 2013. On Pastness: A Reconsideration of Materiality in Archaeological Object Authenticity. Anthropological Quarterly. Vol. 82:2. Pp. 427-444.

Johnson, M. 2006. On the Nature of Theoretical Archaeology and Archaeological Theory. Cambridge Archaeological Dialogues. Vol. I3. Pp. II7-I32.

Latour, B. I993. We Have Never Been Modern. Cambridge, Mass: Harvard University Press.

Latour, B. 1999. Pandora's Hope: Essays on the Reality of Science Studies. Cambridge, Mass: Harvard University Press.

Latour, B. 2005. Reassembling the Social: An Introduction to Actor-Network-Theory. Oxford: Oxford University Press.

Law, J. \& Hassard, J. 1999. Actor Network Theory and After. Oxford: Blackwell.

Lucas, G. 20I2. Understanding the Archaeological Record. Cambridge. Cambridge University Press.

Meillasoux, Q. 2008. After Finitude: An Essay On The Necessity Of Contingency. London: Continuum.

Morton, T. B. 2010. The Ecological Thought. Cambridge: Harvard University Press.

Morton, T. B. 20I r. Sublime Objects. Speculations. Vol. 2. Pp. 207-227.

Normark, J. 2006. The Roads In-Between: Causeways and Polyagentive Networks at Ichmul and Yo'okop, Cochuah Region. GOTARC Serie B. Gothenburg Archaeological Theses no 45.

Normark, J. 2008. The Triadic Causeways of Ichmul: Virtual Highways Becoming Actual Roads. Cambridge Archaeological Journal. Vol. I8:2. Pp. $215-238$.

Normark, J. 20IO. Involutions of Materiality: Operationalising a Neomaterialist Perspective through the Causeways at Ichmul and Yo'okop. Journal of Archaeological Method and Theory. Vol. I7. Pp. I32-173.

Olsen, B. 2003. Material Culture after Text: Re-membering Things. Norwegian Archaeological Review. Vol. 36. Pp 87-I04.

Olsen, B. 2007. Keeping Things at Arm's Length: A Genealogy of Asymmetry. World Archaeology. Vol. 39. Pp 579-588.

Olsen, B. 20Io. In Defense of Things: Archaeology and the Ontology of Objects. Plymouth: Altamira Press. 
Olsen, B. 20I 2. After Interpretation: Remembering Archaeology. Current Swedish Archaeology. Vol. 20. Pp. II-34.

Olsen, B., Shanks, M., Webmoor, T. \& Witmore, C. 20I 2. Archaeology: The Discipline of Things. Berkeley: University of California Press.

Pálsson, G. 1996. Human-environmental Relations: Orientalism, Paternalism and Communalism. In: Descola, P. \& Pálsson, G. (Eds). Nature and Society: Anthropological Perspectives. London: Routledge, 63-8I.

Patrik, L. E. 1985. Is There an Archaeological Record? Advances in Archaeological Method and Theory. Vol. 8. Pp. 27-62.

Pauketat, T. R. 200ra. Practice and History in Archaeology: An Emerging Paradigm, Anthropological Theory. Vol. 73. Pp. 73-98.

Richards, C. 2004. A Choreography of Construction: Monuments, Mobilization and Social Organization in Neolithic Orkney. In: Cherry, J., Scarre, C. \& Shennan, S. (Eds). Explaining Social Change: Studies in Honour of Colin Renfrew. Cambridge. Pp. IO3-II4.

Robb, J. E. 2007. The Early Mediterranean Village: Agency, Material Culture, and Social Change in Neolithic Italy. Cambridge: Cambridge University Press.

Robb, J. E. 20I3a. Material Culture, Landscapes of Action, and Emergent Causation: A New Model for the Origins of the European Neolithic. Current Anthropology. Vol. 54:6. Pp. 657-683.

Robb, J. E. 20I3b. History in the Body: Scale of Belief. In: Robb, J. E. \& Pauketat, T. R. (Eds). Big Histories, Human Lives: Tackling Problems of Scale in Archaeology. School of Advanced Research, Advance Research Seminars. Pp. 77-99. Santa Fe, N.M: School for Advanced Research Press.

Robb, J. E. 20r4. The Future of the Neolithic: A New Research Agenda. In: Whittle, A. \& Bickle, P. (Eds). Early Farmers: A View from Archaeology and Science. London: British Academy I98. Pp. 2 I-38.

Robb, J. E. \& Pauketat, T. R. 20I3. From Moments to Millennia: Theorizing Scale and Change in Human History. In: Robb, J. E. \& Pauketat T. R. (Eds). Big Histories, Human Lives: Tackling Problems of Scale in Archaeology. School of Advanced Research, Advance Research Seminars. Pp. 3-33. Santa Fe, N.M: School for Advanced Research Press.

Shanks, M. 2007. Symmetrical Archaeology. World Archaeology. Vol. 39. Pp. 589-596.

Shanks, M. \& McGuire, R. H. 1996. The Craft of Archaeology. American Antiquity. Vol. 6r. Pp. 75-88.

Shanks, M. \& Tilley, C. 2007. Material Culture. In: Knell S. J. (Ed.). Museums in the Material World. London: Routledge.

Shanks, M. \& Webmoor, T. 20I2. A political economy of visual media in archaeology. In: Bonde, S. \& Houston, S. (Eds). Re-presenting the Past: Archaeology through Image and Text. Oxford: Joukowsky Institute Publications/Oxbow. Pp. 85-108.

Taylor, W. W. I948. A Study of Archaeology. American Anthropologist. Memoir 69. Washington, D.C.

Thomas, J. S. I996. Time, Culture and Identity: An Interpretive Archaeology. London: Routledge.

Thomas, J. S. 20I5. Why 'The Death of Archaeological Theory?' In: Hillerdal, C. \& Siapkas, J. (Eds). Debating Archaeological Empiricism: The Ambiguity of Material Evidence. Oxford: Routledge Studies in Archaeology. 
Webmoor, T. 2005. Mediational Techniques and Conceptual Frameworks in Archaeology: A Model in "Mapwork" at Teotihuacan, Mexico. Journal of Social Archaeology. Vol. 5:I. Pp. 52-84.

Webmoor, T. 2007. What about 'One More Turn after the Social' in Archaeological Reasoning? Taking Things Seriously. World Archaeology. Vol. 39:4. Pp. 547-562.

Webmoor, T. 20I4. Algorithmic Alchemy, or the Work of Code in the Age of Computerized Visualization. In: Carusi, T., Hoel, A.S., Webmoor, T. \& Woolgar, S. (Eds). Visualization in the Age of Computerization. London and New York: Routledge. Pp. 23-56.

Webmoor, T. \& Witmore, C. 2008. Things Are Us! A Commentary on Human/Things Relations under the Banner of 'Social' Archaeology. Norwegian Archaeological Review. Vol. 4I:I. Pp. 53-70.

Witmore, C. L. 2006. Vision, Media, Noise and the Percolation of Time: Symmetrical Approaches to the Mediation of the Material World. Journal of Material Culture. Vol. II:3. Pp. 267-292.

Witmore, C. L. 2007. Symmetrical Archaeology: Excerpts of a Manifesto. World Archaeology. Vol. 39. Pp. 546-562.

Whittle, A. 2007. Going Over: People and Their Times. In: Whittle, A. \& Cummings, V. (Eds). Going Over: The Mesolithic-Neolithic Transition in North-West Europe. Oxford: British Academy I44. Pp. 6I7-628.

Whittle, A. \& Cummings, V. 2007b. Introduction: Transitions and Transformations. In: Whittle, A. \& Cummings, V. (Eds). Going Over: The Mesolithic-Neolithic Transition in North-West Europe. Oxford: British Academy I 44.

\section{Unpublished sources}

Garcia-Rovira, I., Thomas, J. \& Bishop, L. 20I5. A report on the fourth season of excavation at Dorstone Hill, Dorstone CP (unpublished report).

Thomas, J., Garcia-Rovira, I. \& Bishop, L. 20I4. A report on the third season of excavation at Dorstone Hill, Dorstone CP (unpublished report). 